DOI: 10.19195/0137-1150.163.32

\title{
BEATA SIWEK
}

Katolicki Uniwersytet Lubelski Jana Pawła II, Lublin, Polska

beata.siwek@kul.pl

\section{Starość niedoskonała. Doświadczenie starości w dramatach Końcówka Samuela Becketta i Wieczór Alaksieja Dudaraua}

Można by zaryzykować stwierdzenie, że dramat, a tym samym także ściśle z nim związany teatr, ma z tematem starości pewien kłopot. Starość jest bowiem zwykle nieestetyczna, nieatrakcyjna, przygnębiająca i rozpaczliwie smutna. Co ma zatem do zaoferowania współczesnemu odbiorcy - czytelnikowi, a tym bardziej widzowi? Czy jest w stanie zniewolić i zachwycić swoją głębią, zaintrygować czy wywołać autentyczne wzruszenie?

Temat starości jest nader często ignorowany czy też spychany na plan dalszy. Stosunkowo rzadko bywa zatem głównym przedmiotem refleksji dramatopisarskiej czy teatralnej. Jednakże istnieje grupa tekstów dramatycznych, które podejmują rozważania nad starością i ukazują ją poprzez wykorzystanie różnych konwencji, rozmaitych estetyk, odmiennych strategii i środków wyrazu — to w konwencji tragicznej, naznaczonej nieustanną katastrofą i przeczuwalnym wybuchem pustki ${ }^{1}$, to $\mathrm{z}$ lekkim przymrużeniem oka ${ }^{2}$, sentymentalnie i melodramatycznie ${ }^{3}$, to nostal-

${ }^{1}$ Przesłanie dramatu Krzesła Eugène Ionesco opisał następująco: ,... tematem sztuki nie jest jakieś posłanie ani porażki życiowe, ani moralna katastrofa Starych, ale właśnie krzesła, to znaczy nieobecność materii, nierealność świata, pustka metafizyczna: tematem sztuki jest nic [...] nic staje się słyszalne, konkretyzuje się, to szczyt nieprawdopodobieństwa". Z listu Eugene Ionesco do Sylvaina Dhomme'a, cyt. za: M. Piwińska, Przedmowa, [w:] E. Ionesco, Teatr, t. I, Warszawa 1967, s. 37.

${ }^{2}$ W takiej konwencji utrzymany jest dramat Hanocha Levina Pakujemy manatki. Ze względu na komiczne potraktowanie tematu śmierci, tekst ten wpisuje się w konwencję tragifarsy.

${ }^{3}$ Melodramatyczne, sentymentalne oblicze starości ukazuje Hanoch Levin w dramacie Romantycy. W utworze tym nie brakuje co prawda specyficznej dla izraelskiego dramatopisarza ironii i groteski, łączenia żartu — nieraz nawet szyderczego — z tonem poważnym. 
gicznie i przejmująco ${ }^{4}$, wreszcie z życzliwością i zachwytem, z niekłamaną fascynacją dojrzałością i doświadczeniem życiowym osób starych ${ }^{5}$. Dramaty, w których doświadczenie starości zniewala odbiorcę autentycznością przeżyć, duchowych rozterek, uniesień, a czasem też wątpliwości: Krzesła (Les Chaises, 1952) Eugène Ionesco, Niespokojna starość (Беспокойная старость, 1952) Leonida Rachmanowa, Ostatnia taśma (Krapp’s Last Tape, 1958), Szczęśliwe dni (Happy days, 1961), Wtedy gdy (That time, 1976) Samuela Becketta, Józef i Maria (Josef und Maria, 1980) Petera Turriniego, Starość jest piękna (Alt heißt schön, 1980) Esther Vilar, Ja, Fuerbach (Ich, Feuerbach, 1986) Tankreda Dorsta, Pierwsza młodość (Première Jeunesse, 1987) Christiana Giudicelli, Śmieszny staruszek (1963), Stara kobieta wysiaduje (1968) i Kartoteka rozrzucona (1994) Tadeusza Różewicza, Pakujemy manatki. Komedia na osiem pogrzebów (The Suitcase Packers. Orzej Mizwadot, 1983), Zimowy pogrzeb (Halwaja chorpit, 1986) i Requiem (1999) Hanocha Levina, Kwartet (Quartet, 1999) Ronalda Harwooda, Baba Chanel (Баба Шанель, 2010) Nikołaja Kolady. Wymienione utwory bynajmniej nie wyczerpują listy tekstów zainspirowanych tematem starości, aczkolwiek giną w gąszczu dramatów traktujących o młodości, kulcie ciała, afirmacji życia i piękna.

Mają jednak wyjątkową głębię, prawdę przekazu, ton dotykający najczulszych strun ludzkiej duszy. Spróbujmy zatem zrekonstruować literackie doświadczenie starości w dwóch wybranych tekstach dramatycznych — dramacie Końcówka (Fin de partie, 1957) Samuela Becketta (1906-1989) i Wieczór (Beyap, 1983) białoruskiego dramatopisarza Uładzimira Dudaraua (ur. 1950). Konfrontowanie z sobą dwóch tekstów literackich zawsze musi rodzić pytania o jego zasadność, o sieć relacji wiążących porównywane utwory. A relacji tych jest w przypadku naszych tekstów niemało. Najważniejszym elementem jest sposób ukazania tematu starości. Obydwaj twórcy eksponują końcowy jej etap, schyłek, czy może raczej — jak metaforycznie określił to Dudarau - wieczór życia. W obu dramatach wielokrotnie pojawia się temat śmierci. Śmierć i starość są tu ukazane jako doświadczenia wzajemnie się warunkujące. Świat bohaterów analizowanych dramatów dobiegł (bądź w przypadku niektórych bohaterów dobiega) do kresu. Śmierć jest nieustannie obecna w świadomości wszystkich postaci dramatu i to nie tylko tych, którzy z racji wieku myślą o jej nieuchronności i bliskości. „Skończone, skończyło się, kończy się już, to chyba się już kończy. (Pauza) Ziarnko do ziarnka, po jednym, aż nagle, któregoś dnia, jest stos, mały stos, niemożliwy stos"6 — mówi bohater Końcówki Clov w scenie rozpoczynającej utwór.

${ }^{4}$ Monodram Tankreda Dorsta $J a$, Feuerbach to przejmująca opowieść o rozterkach i dylematach starego aktora, który po wielu latach postanowił powrócić na scenę. W polskich realizacjach sztuki niezapomniane kreacje Feuerbacha stworzyli Jan Łomnicki (Teatr Dramatyczny w Warszawie) oraz Piotr Fronczewski (Teatr Ateneum).

${ }^{5}$ Warto tu przypomnieć dramat Nikołaja Kolady Baba Chanel czy też sztukę Esther Villar Starość jest piękna.

${ }^{6}$ S. Beckett, Końcówka, [w:] idem, Dramaty, przekład, wstęp i oprac. A. Libera, Wrocław 1999, s. 114. 
Drugi element narzucający się wprost — analogiczny sposób konstrukcji postaci dramatycznych. W utworach tych mamy do czynienia z „zespołem postaci”, które pełnią funkcję „,bohatera głównego” — staruszkowie Nagg i Nell, ich kaleki syn Hamm oraz jego opiekun Clov (w Końcówce), a także sędziwi przyjaciele - Hanna, Wasil i Hastryt (w dramacie Wieczór). W sposobie kreślenia postaci widoczne jest łączenie cech istotnych dla ujawnienia psychiki i motywów postępowania bohaterów z cechami przypadkowymi, mało znaczącymi. Choć te przypadkowe, nieistotne z pozoru cechy urastają nieraz do rangi niezwykle ważnych i wyznaczających kierunek interpretacji. Świadczą już o tym chociażby wstępne didaskalia utworów. Jak zauważa Maciej Kawka w artykule Czy didaskalia to tekst poboczny dramatu?, to właśnie dzięki didaskaliom dialogi uzyskują wymiar dramatyczny. Ich działanie bowiem jest oparte nie tylko na językowym mechanizmie działania na tekście, ale też „kreacyjnej sile illokucji metatekstowej”7. To one współtworzą teatralny kształt dramatu.

W dramacie Końcówka Beckett wykorzystuje drobiazgowe opisy, dzięki którym dopełnia charakterystyki postaci, czasem intryguje i niepokoi:

Hamm, w szlafroku, w filcowej mycce na głowie, z wielką chustą poplamioną krwią na twarzy, z gwizdkiem wiszącym u szyi, z pledem na kolanach, w grubych skarpetach na nogach, zdaje się spać. Clov patrzy na niego. Krótki śmiech. Idzie do drzwi, zatrzymuje się, odwraca, przygląda się scenie, zwraca się w stronę widowni ${ }^{8}$.

W podobnej konwencji utrzymane są didaskalia dramatu Wieczór Alaksieja Dudaraua:

Rozeszli się. Wasil zaniósł wiadro z wodą do chaty. Z drugiej strony ulicy wychodzi Hastryt. Maleńki, żwawy i zaczepny dziadek. Wszystko w jego wyglądzie jest ostre: i broda, i plecy, i łokcie, i kolana, i nos. Przyszedł po wodę z czajnikiem. Wyciągnął, nalał do czajnika, wypił z dzióbka. Postał, westchnął, przysiadł na ławce9 .

Z tak szczegółowymi, drobiazgowymi didaskaliami będziemy się spotykać w różnych partiach analizowanych tekstów. W przywołanych dramatach ukazana jest ponadto bardzo zbliżona koncepcja tragizmu — tragizm tkwi w człowieku, który nie potrafi, choć usilnie próbuje, nadać sensu własnej egzystencji. Nie bez znaczenia jest też fakt, że zarówno Beckett, jak i Dudarau przenieśli punkt ciężkości akcji z wydarzeń zewnętrznych na świat wewnętrzny kreowanych postaci, co łączyć należy z postulatami estetyki absurdystycznej, w której taka strategia była obecna stosunkowo często. Łączy oba teksty również koncentracja na egzystencjalnym i metafizycznym wymiarze starości. Postaci dramatyczne ukazane w analizowanych utworach to ludzie, których nikt już nie potrzebuje. Jedynie oni potrzebują siebie nawzajem. Ich życie wyznaczane jest przez tragizm pamięci. Są pozostawieni sami sobie w głuchej, przez wszystkich zapomnianej wiosce,

${ }^{7}$ M. Kawka, Czy didaskalia to tekst poboczny dramatu?, „Annales Academiae Paedagogicae Cracoviensis", Folia 9, 2003, s. 273.

${ }^{8}$ S. Beckett, op. cit., s. 114.

9 А. Дудараў, Вечар, [w:] idem, Князь Вітаўm. П’есы, Мінск 2006, s. 62. Przekład własny. 
jak w dramacie Dudaraua, czy też w zamkniętej, niedostępnej, przypominającej pułapkę przestrzeni pokoju i przeżywają dramat rozpadu świata ${ }^{10}$. Silnie obecny w obu tekstach jest też motyw oczekiwania, nadziei na zmianę. Czekanie staje się najważniejszym rodzajem aktywności - fizycznym bezruchem dokonującym cudów na poziomie duchowym, mającym ocalającą moc. Podobieństwo zaznacza się także na płaszczyźnie określeń temporalnych. Zarówno białoruski dramatopisarz, jak i autor Końcówki eksponują te wymiary czasowe, które związane są ze zmierzchem, brakiem światła, nocą. Spróbujmy zatem przyjrzeć się bardziej szczegółowo wymienionym zagadnieniom i zrekonstruować na podstawie przeprowadzonych analiz literacki obraz starości. Ze względu na ogromny potencjał sensotwórczy dramatów prezentowane ujęcie tego ważnego doświadczenia egzystencjalnego będzie siłą rzeczy fragmentaryczne i niepełne.

O sztuce Samuela Becketta wybitny dramatopisarz Eugène Ionesco pisal: „Sztuka Becketta Końcówka, którą właśnie przeczytałem, przewyższa, być może, Czekając na Godota. To arcydzieło, i sądzę, że teatry powinny je sobie wzajemnie wyrywać"11. Ten jednoaktowy tekst dramatyczny przemawia poprzez rozbudowany symbol, który jest niczym innym, jak tylko zobrazowaniem końca świata. Cztery postaci dramatyczne sztuki to osoby samotne, opuszczone i kalekie. Stary Nagg i jego żona Nell mieszkają w kubłach na śmieci, z których od czasu do czasu wychylają jedynie głowę. Taki sposób kreacji postaci ma zapewne w dramacie znaczenie symboliczne. Beckett eksponuje bowiem rzeczywistość świata minionego, przeszłość, której Nagg i Nell stają się żywym symbolem. W samotnym domu mieszka też ociemniały syn staruszków - Hamm (w fotelu na kółkach). Opiekuje się nim Clov, którego największym marzeniem jest odejście. Jego wizja pojawia się kilkakrotnie na płaszczyźnie wyobrażeniowej. W rozmowie z Hammem tak oto projektuje swoją przyszłość:

Otwieram drzwi celi i idę. Jestem tak zgarbiony, że gdy otwieram oczy, widzę tylko swe stopy i skrawek czarniawego pyłu między nimi. Mówię sobie, że ziemia zgasła, choć nigdy nie widziałem, żeby płonęła. (Pauza) To się dzieje poza mną. (Pauza) A kiedy padnę, zapłaczę... ze szczęścia ${ }^{12}$.

Bohaterowie Końcówki większą część doby śpią lub pogrążeni są w bezsennym letargu. Zastosowana w dramacie konwencja oniryczna potęguje dramatyzm losów postaci dramatu, ich bezsilność wobec własnego losu. Starość jest ukazana przez Becketta jako okres, w którym świadomość człowieka, zdecydowanie bardziej niż we wcześniejszych okresach życia, zdominowana jest przez przemija-

10 Przestrzeń tę Beckett konstruuje we wstępnych didaskaliach: „Wnętrze bez mebli. Światło szarawe. W głębi, wysoko, w lewej i prawej ścianie, dwa okienka zasłonięte zasłonami. Z przodu po prawej drzwi. Przy drzwiach obraz zawieszony frontem do ściany. Z przodu po lewej, tuż obok siebie, dwa kubły na śmieci, przykryte starym prześcieradłem. Pośrodku, w fotelu na małych kółkach, przykryty starym prześcieradłem, siedzi Hamm”. S. Beckett, op. cit., s. 113.

${ }^{11}$ Z Programu Teatralnego. Teatr Dramatyczny Wałbrzych, Premiera 1 października 1998, s. 1.

${ }^{12}$ S. Beckett, op. cit., s. 171. 
nie, którego widocznym i jakże bolesnym śladem jest „zużywanie się”, zanikanie sprawności życiowych - i fizycznych, i nierzadko psychicznych. Wprowadzone do utworu dialogi odwołujące się do minionych doświadczeń pełnią podwójną funkcję. Z jednej strony wyobraźnia stanowi źródło doskonałych przedstawień, którymi karmi się świadomość staruszków, z drugiej zaś jest wyrazem dotkliwej pustki dokonującej anihilacji doświadczenia przeszłości. Jak trafnie zauważa Jakub Momro, paradoks siły wyobraźni polega na tym, że powołuje ona do istnienia konkretne byty, ale też uniemożliwia ich pełną obecność. Nie tyle powołuje do życia inne światy, ile jednocześnie jest miejscem, „w którym świadomość dociera do własnego kresu, w którym ujawniają się jednocześnie i nierozdzielnie dwie jej modalności: ustanawiania i wymazywania rzeczywistości, a zarazem ożywiania samej siebie i umierania"13. Podróż Nell w głąb świata, jakiego już przecież nie ma, ponieważ stał się wspomnieniem, jest w rzeczywistości podróżą do miejsca duchowej pustki: w to?

NELL: Na jeziorze Como. (Pauza) W popołudnie kwietniowe. (Pauza) Uwierzyłbyś

NAGG: W co?

NELL: Że pływaliśmy łódką po jeziorze Como. (Pauza) W popołudnie kwietniowe.

NAGG: Poprzedniego dnia były nasze zaręczyny.

NELL: Zaręczyny!

NAGG: Tak się śmiałaś, żeśmy się wywrócili. Mogliśmy się utopić.

NELL: Bo czułam się szczęśliwa.

NAGG: E tam, skąd, to z mojej historyjki. Najlepszy dowód, że jeszcze się z niej śmiejesz. Za każdym razem.

NELL: Tam było głęboko, głęboko. I było widać dno. Takie białe. Takie czyste ${ }^{14}$.

Przytoczone słowa stanowią wyraz tęsknoty staruszki za nieskalaną naturą rzeczy, za światem wartości najwyższych, symbolizowanych tu przez kolor biały. Nieprzypadkowo zatem tak często powracał będzie w dramacie Becketta motyw dzieciństwa, okresu niczym niezmąconego szczęścia, radości, beztroski. W jednej ze scen Hamm prosi Clova: ,Jeszcze jedno. (Clov zatrzymuje się) Ostatnia posłuuuga. (Clov wychodzi) Przykryj mnie. (Długa pauza)". Ta zagadkowa scena, jak zauważa Dariusz Klimczak, nawiązuje bezpośrednio do motywu dzieciństwa. Hamm pragnie, aby motyw zaśnięcia nie był dla niego zaskoczeniem, chce być okryty, tak jak matka okrywa niemowlę. Powrót zatem do błogiego i niewinnego stanu dziecięctwa to ucieczka od okrutnej rzeczywistości ${ }^{15}$.

Nie brakuje w dramacie Becketta odwołań do cielesnego, fizycznego aspektu starości. Starość upośledza zmysły, ale nie uwalnia o zmysłowych pokus, nie prowadzi do prymatu ducha nad ciałem i zanurzenia się jedynie w kontemplacji

13 J. Momro, Literatura świadomości. Samuel Beckett - Podmiot - Negatywność, Kraków 2010, s. 435.

14 S. Beckett, op. cit., s. 127.

15 D.P. Klimczak, Medytacja nad Pustka. Konteksty buddyjskie w „Końcówce” $i$,Szczęśliwych dniach” Samuela Becketta, „Przestrzenie Teorii” 2004, nr 3/4, s. 350. 
i religijnej medytacji ${ }^{16}$. Cielesność pełni w tym dramacie funkcję ontologiczną. Jest ona widomym znakiem wskazującym na ściśle określoną obecność człowieka w czasoprzestrzeni:

NELL: Co się stało, staruszku? (Pauza) Masz chęć?

NAGG: Spałaś?

NELL: Skąd!

NAGG: Pocałuj.

NELL: Nie da się.

NAGG: Spróbujmy.

Dwie głowy z wysiłkiem wychylają się ku sobie, po czym nie dotknąwszy się, wracają z powrotem na miejsce

NELL: Po co codziennie ta komedia?

Pauza

NAGG: Wypadł mi ząb.

NELL: Kiedy?

NAGG: Wczoraj go jeszcze miałem.

NELL (elegijnie): Ach, wczoraj!

Z wysiłkiem zwracają się ku sobie

NAGG: Widzisz mnie?

NELL: Słabo. A ty?

NAGG: Co?

NELL: Czy mnie widzisz?

NAGG: Słabo.

NELL: Tym lepiej, tym lepiej.

NAGG: Nie mów tak. (Pauza) Wzrok nam osłabł.

NELL: Tak.

Pauza. Odwracają się od siebie ${ }^{17}$.

Przytoczony dialog pozwala stwierdzić z całą pewnością, że w języku starości istotną rolę odgrywają przemilczenia, niedopowiedzenia. Ta swoista formuła niedokończoności - jak zauważa Tadeusz Sławek — powoduje, że dialogiczna warstwa tekstów okazuje się nierzadko katalogiem przypadkowych dygresji, skojarzeniowych ciągów myśli, nieuporządkowanych, chaotycznych konstrukcji ${ }^{18}$. $\mathrm{O}$ ile są one stosunkowo często niezrozumiałe dla odbiorcy, o tyle stanowią bez wątpienia swoisty kod starości, odczytywany przez pryzmat wspólnych wieloletnich przeżyć i życiowych doświadczeń bohaterów. Zdarza się też jednak, że trudności komunikacyjne między bohaterami powodują swoistą izolację człowieka, stwarzają dystans tak trudny do przezwyciężenia. Dystans ów narasta za sprawą zastosowanych w utworze rozwiązań przestrzennych. Jak wspomniałam, Beckett umieszcza swoich bohaterów w kubłach na śmieci. Stary człowiek staje

${ }^{16}$ Zob. więcej na ten temat: S. Cavell, Ending the Waiting Game: A Reading of Beckett's Endgame, [w:] idem, Must We Mean What We Say?: A Book of Essays, Cambridge 1976, s. 142-146.

${ }^{17}$ S. Beckett, op. cit., s. 123-124.

18 T. Sławek, Trakt starego człowieka. Próba polityki starości, [w:] Egzystencjalne doświadczenie starości w literaturze, red. E. Gleń, J. Jokiel, M. Szladowski, Opole 2008, s. 18. 
się niewidoczny dla innych, tak jakby nigdy nie istniał. Nie zabija jednak w sobie pragnienia uwagi, chce jeszcze cokolwiek znaczyć:

Mam nadzieję, że przyjdzie jednak jeszcze taki dzień, gdy naprawdę będziesz potrzebował, abym cię słuchał, i będziesz potrzebował usłyszeć mój głos, czyjkolwiek głos. (Pauza) Tak, mam nadzieję, że tego dożyję, gdy wezwiesz mnie, tak samo jak kiedy byłeś mały i bałeś się w nocy, a ja byłem twoją jedyną nadzieją ${ }^{19}$ [mówi Nagg do syna].

W Końcówce Becketta, podobnie jak w dramacie Czekając na Godota, ważną rolę odgrywa motyw Chłopca. Jednakże w Końcówce nie jest on postacią dramatu, lecz pojawia się tylko w relacji Clova. Postać ta, niejednoznaczna w swojej funkcji i wymowie, stosunkowo często jest interpretowana jako alegoryczny motyw Chłopca-Zbawiciela, wywodzący się z europejskiej tradycji testamentowej oczekiwania na przyjście Mesjasza ${ }^{20}$. Jest on jednak tym bardziej oczekiwany, że bohaterowie Becketta żyją w świecie klaustrofobicznym, zamkniętym i niedostępnym. To w tym świecie rozgrywa się tragedia ich istnienia ${ }^{21}$. Przestrzeń zamknięta staje się w tym utworze więzieniem i duszy, i ciała ${ }^{22}$. Język sztuki Samuela Becketta jest niezwykle prosty, niemało w nim zabiegów retorycznych zamilknięć, wykrzyknień, pytań, eliptycznych sformułowań, jest on wieloznaczny i sugestywny. Niemałą rolę odgrywają w jego dramacie zabiegi eufoniczne. Zwraca uwagę również poetyckość tekstu pobocznego. Nierzadko didaskalia podkreślają duchowe potrzeby postaci. W finale Końcówki Hamm wypowiada następujące słowa:

Wołałeś o... (Pauza. Poprawia się) Błagałeś o noc; nadchodzi... (Pauza. Poprawia się) zapada: oto jest. (Powtarza śpiewnie) Błagałeś o noc; zapada: oto jest ${ }^{23}$.

Jak trafnie zauważa Dariusz Klimczak, filozofia końca zbudowana jest w dramacie Becketta oksymoronicznie. Obsesyjne wręcz przywoływanie końca ma swój głęboki sens, ponieważ jest to tylko reakcja na pragnienie końca doświadczanych utrapień, uśmierzenie zniewalającego bólu, ale też jednocześnie — pragnienie przemiany tego, co stanowi doczesność ${ }^{24}$. Gilles Renard, reżyser Końcówki w Teatrze Dramatycznym w Wałbrzychu pisał:

Końcówka jest sztuką intrygującą, zarazem smutną i śmieszną — te wszystkie skomplikowane związki sadomasochistyczne łączące cztery nieszczęsne istoty ludzkie umieszczone w cylindrycznej bezkresnej przestrzeni, ten cały Beckettowski świat, który dobiega

19 S. Beckett, op. cit., s. 151.

${ }^{20}$ Zob. więcej na ten temat: D.P. Klimczak, op. cit., s. 342. D. Klimczak takich nawiązań do tradycji chrześcijańskiej odnajduje w tekście Becketta zdecydowanie więcej, np. motyw pustego grobu, który wyrażał zwycięstwo Jezusa nad śmiercią.

21 Ibidem, s. 340.

${ }^{22}$ Ważną rolę w konstrukcji przestrzeni sztuki odgrywa gra światła i cienia podkreślająca stan emocjonalny postaci. Zob. na ten temat: J. Knowlson, Light and Darkness in the Theatre of Samuel Beckett, London 1972.

23 S. Beckett, op. cit., s. 172.

24 D.P. Klimczak, op. cit., s. 341. 
końca, dotyka Nicości, a jednak nie może się skończyć, i w którym każde ego jest nieuchwytne, a przecież istnieje ${ }^{25}$.

Przesunięcie punktu ciężkości z akcji na dialog, koncentracja na motywie przemijania i starości, rozbudowana retoryka i dbałość o sceniczne detale to najważniejsze elementy uobecniające się w dramacie Alaksieja Dudaraua Wieczór ${ }^{26}$. Utwór ten można by określić jako dramat psychologiczny, w którym rozważane są podstawowe kwestie dotyczące ludzkiej kondycji. Pytania, które stawiają sobie bohaterowie utworu, dotyczą kwestii fundamentalnych: Jaki jest sens ludzkiego życia? Kim jest Bóg? Jak należy postępować, żeby u schyłku swojego życia móc spojrzeć sobie w oczy? Życie trzech bohaterów dramatu: Wasila, Hanny i Hastryta (zwanego przez przyjaciół Mikitą), sprowadza się w zasadzie do rozpamiętywania przeszłości, bezowocnego oczekiwania na „tajemniczego Godota", niczym w Beckettowskich dramatach. Przeszłość w dramacie Wieczór przedstawiona jest w wymiarze indywidualnego życia, a ewokowane wydarzenia mają charakter osobisty. Przemijanie i starość ukazane są przez białoruskiego dramatopisarza jako nieuchronność wpisana w naturalny sposób w los ludzi, tak jak oddychanie czy dochodzenie do kresu ${ }^{27}$. Podstawowym problemem, z jakim borykają się postaci dramatu, jest samotność i wyizolowanie. Te doświadczenia stanowią treść codziennej rzeczywistości staruszków, z którą radzą sobie coraz trudniej i od której nie ma już ucieczki. Życiowa monotonia, brak perspektyw na jakąkolwiek zmianę, swoiste uwięzienie w przestrzeni domu stanowią wytłumaczenie ich anormalnych zachowań, swoistych dziwactw, które nasilają się z każdym dniem. Hastryt — nie wiedzieć czemu — nosi w czajniku wodę ze studni, Wasil lubuje się w pisaniu anonimów do władz gminnych i rozmawia ze słońcem, któremu zwierza się z najbardziej intymnych przeżyć i wzruszeń, Hanna prowadzi niemy dialog z portretem swojego dawno już zmarłego męża. Uwagę zwraca też charakterologiczne zróżnicowanie postaci. Hastryt jest nierzadko wulgarny i porywczy, Wasil skłonny do refleksji i zadumy, Hanna łagodna i ufna, ale jednocześnie nie umie odnaleźć sensu swojego życia. W rozmowie z Wasilem, w drugim akcie dramatu żali się:

Baba powinna być łagodna, na Słońce, jak mówisz, częściej spoglądać [...] A ja... Tylko walczyłam i bałam się wojny... Tylko dzieci rodziłam i chowałam do ziemi... Praco-

25 Z Programu Teatralnego. Teatr Dramatyczny Wałbrzych..., s. 3.

${ }^{26}$ Wieczór Alaksieja Dudaraua należy do najbardziej znanych białoruskich tekstów dramatycznych. Swoją popularność zawdzięcza w dużej mierze doskonałym realizacjom teatralnym. Wystawiany był bowiem przez Narodowy Akademicki Teatr im. Janki Kupały (reż. B. Eryn, 1984), Brzeski Obwodowy Teatr Dramatyczny (reż. M. Truchan, 1986), Homelski Obwodowy Teatr Dramatyczny (reż. H. Prymak, 1986), a także przez teatry rosyjskie i ukraińskie. Zob. Тэатральная Беларусь. Энщькллапедыля, т. 1, red. А.С. Сабалеўскі, Мінск 2002, s. 207-208.

27 Zob. więcej na temat twórczości Alaksieja Dudaraua: B. Siwek, Wolność ukrzyżowana. Rzecz o biatoruskim dramacie i teatrze, Lublin 2011, s. 159-183. 
wałam, pracowałam, pracowałam... a teraz na tym świecie nic mi nie pozostało... I po co przyszłam na świat? ${ }^{28}$

Te egzystencjalne dylematy i rozterki nieobce są pozostałym postaciom dramatu. Alaksiej Dudarau celowo wzmacnia retoryczną warstwę dzieła, silnie liryzuje wypowiedzi postaci, wprowadza zróżnicowane zabiegi składniowe (w szczególności aposiopesis, pytanie retoryczne i apostrofę), aby spotęgować tragizm jednostkowych losów postaci dramatu, ukazać uczucie ich zagubienia i strachu przed tym, co nieznane. Nie brakuje jednakże w utworze białoruskiego twórcy momentów ocierających się o groteskę, zaskakujących sytuacyjnym komizmem i humorem. Zaskakują one tym bardziej że służą ukazaniu złożonych problemów egzystencjalnych, z którymi zmagają się bohaterowie dramatu. To one właśnie są impulsem do rozważań nad starością i śmiercią, to one stanowią wyraz metafizycznych poszukiwań i pragnień. Groteskowy stosunek do śmierci jest próbą jej oswojenia, nadania jej pozorów zwyczajności, oczywistej konieczności:

Hastryt: Kiedy zamierzasz umrzeć?

Wasil (bez pauzy): W środę...

Hastryt (zakłopotany): W najbliższą, czy jak?

Wasil: A w którą, to jeszcze nie wiem, ale że w środę to pewne jak amen w pacierzu. Najlepszy dzień. Umrę sobie, znaczy się, o poranku... Nie! nie! Po obiedzie. Obmyją mnie wodą z tej studni...

Hastryt: Ale ona zimna...

Wasil: Dla ciebie zimna, ale dla mnie w sam raz... No, cały czwartek poleżę sobie w chacie... W piątek, znaczy się, na cmentarz, a potem to już we wszystkie niedziele wspominajcie... Pijcie, bawcie się aż do poniedziałku... Zostawię na to setkę, albo i dwie...

Hastryt (ze złością). Kłamiesz! Nie wierzę. I ty się boisz. Powinieneś się bać, a nie... Co widziałeś w życiu, żeby z lekką duszą śmierć przyjmować?

Wasil: Wszystko trzeba robić z lekką duszą... ${ }^{29}$

Pozorne traktowanie śmierci z przymrużeniem oka jest też próbą unieważnienia strachu przed śmiercią. Paradoksalnie, to właśnie poczucie zbliżania się do kresu życia powoduje gęstnienie marzeń, planów i tęsknot:

Gdyby można było... Gdyby drugie życie... Ja... Niczego by nie było... Uczyłem ludzi głupio żyć, a powinienem bawić dzieci, chleb wypiekać i patrzeć na Słońce... To jest święte... To wszystko... ${ }^{30}$ [mówi Hastryt, żegnając się ze światem]

Słowa te świadczą niewymownie o tym, że Alaksiej Dudarau w swojej koncepcji postaci przywiązywał ogromną wagę do świata duchowego i kwestii wiary, do wewnętrznej przemiany bohaterów. Nierzadko usiłował ukazać ich dążenie do osiągnięcia życiowej równowagi, spokoju, stabilności, które jednak przegrywają $\mathrm{w}$ zderzeniu z niepokojem oczekiwania. Ostatnie słowa wypowiedziane w dramacie ustami Wasila: „Słońce, nasze Słońce — wstawaj! (Przygląda się, wychodzi naprzód.) Hanna! Ktoś idzie! Do wioski idzie... Hanna podchodzi do

28 А. Дудараў, op. cit., s. 84.

29 Ibidem, s. 62.

30 Ibidem, s. 88. 
niego. Stoją, patrzą. Czekają"31, można by potraktować jako swego rodzaju motyw przewodni utworu, jego myśl główną — dramatyzm bezowocnego czekania, swoistą parabolę ludzkiego losu.

Koncepcja postaci tego dramatu zasadza się zatem na motywie czekania. To ono przenika $\mathrm{w}$ tym dramacie wszystko i z jednej strony stanowi podstawowe źródło cierpienia, $\mathrm{z}$ drugiej zaś nadzieję, która - w monotonnym i pełnym cierpienia życiu bohaterów - jest wartością nieocenioną. Można zatem stwierdzić, że w dramacie Wieczór to właśnie ontologiczny kontekst w głównej mierze określa sposób istnienia postaci. Troje starzejących się bohaterów w dramacie Dudaraua chwyta się z całych sił resztek życia, choć i tak skazani są na porażkę. A że mają tego pełną świadomość, tym większy ich smutek, tym bardziej intensywne poszukiwanie ostatnich błysków radości. Nie brakuje w dramacie Dudaraua wątków humorystycznych, licytowania wspomnien. Z jednej strony zatem nie sposób nie śmiać się z ukazanych sytuacji, z drugiej jednak wywołują one uczucie przygnębienia. To zderzenie ironii i groteski, szyderczych nieraz żartów z powagą tym bardziej podkreśla życiowy dramat tych postaci. Bohaterowie Wieczoru nie odgrywają ról, ale ukrywają czasem prawdę o swoich uczuciach, emocjach, nadziejach. Świadomość końca bowiem jeszcze nie jest tak straszna, jak przeczucie umierania w opuszczeniu i samotności. Świat bohaterów Wieczoru jest światem skazanym na przemijanie i utratę wartości. Stąd ogromne pragnienie odnalezienia stałego punktu oparcia. Pojawiają się też wątpliwości natury religijnej, pragnienie harmonii dopełniającego się istnienia ludzkiego. Wszyscy bohaterowie Wieczoru ukazani są w swojej relacji z Bogiem. Jednak każda z tych relacji jest inna. Hastryt widzi w Bogu cudze sacrum i nie jest w stanie się z nim utożsamić. Jego postawa jest bliska tzw. mistyce naturalnej, której bohater doświadcza bez udziału religijności konfesyjnej. Czas jest w dramacie Dudaraua niczym lustro krzywe i pokazuje tylko to, co zmieniło świat na gorszy. Nie brakuje tu zatem pogłębionych refleksji nad bolączkami własnego ciała, przytępionymi zmysłami, ograniczoną chłonnością wrażeń zewnętrznego świata.

Zarówno Wieczór Alaksieja Dudaraua, jak i Końcówka Samuela Becketta to utwory, które zmuszają do refleksji nas sensem ludzkiej egzystencji. Jest nim czasowość zamknięta między Początkiem i Końcem. Samoświadomość własnej czasowości narasta wraz z wiekiem, a poczucie tego, że natura jest ograniczona i śmiertelna, na starość zaczyna wywoływać najbardziej intensywne odczucia i emocje, rodzi - pełne niedowierzania — pytania o sens i koniec wszystkiego. Jednak — jak konstatuje Antoni Libera:

Beckett nie rozwiązuje zagadki egzystencji w duchu nihilistycznym (że jedyny sens świata z punktu widzenia człowieka to absolutny bezsens), ale najwyżej sceptycznym, a przy tym elegijnym: choć ostateczny sens świata ukryty jest przed człowiekiem, nie sposób jednak przypuścić, aby miał się sprowadzać do absolutnej ciemności ${ }^{32}$.

${ }^{31}$ Ibidem, s. 89.

${ }^{32}$ A. Libera, „O Leonardo, czemu tak się trudzisz?”, [w:] idem, Godot i jego cień, Kraków 2009, s. 261. 
Nie rozwiązuje zagadki egzystencji w duchu nihilistycznym także Alaksiej Dudarau. Wszak pozostawia on swoim bohaterom nadzieję, że Godot jednak przyjdzie. Bez tej nadziei nie umieliby już żyć.

\section{Bibliografia}

Beckett S., Końcówka, [w:] idem, Dramaty, przekład, wstęp i oprac. A. Libera, Wrocław 1999.

Cavell S., Ending the Waiting Game: A Reading of Beckett's Endgame, [w:] idem, Must We Mean What We Say?: A Book of Essays, Cambridge 1976.

Kawka M., Czy didaskalia to tekst poboczny dramatu?, „Annales Academiae Paedagogicae Cracoviensis", Folia 9, 2003.

Klimczak D.P., Medytacja nad Pustka. Konteksty buddyjskie w „Końcówce” i „Szczęśliwych dniach” Samuela Becketta, „Przestrzenie Teorii” 2004, nr 3/4.

Knowlson J., Light and Darkness in the Theatre of Samuel Beckett, London 1972.

Libera A., Godot i jego cień, Kraków 2009.

Momro J., Literatura świadomości. Samuel Beckett - Podmiot - Negatywność, Kraków 2010.

Piwińska M., Przedmowa, [w:] E. Ionesco, Teatr, t. I, Warszawa 1967.

Siwek B., Wolność ukrzyżowana. Rzecz o białoruskim dramacie i teatrze, Lublin 2011.

Sławek T., Trakt starego człowieka. Próba polityki starości, [w:] Egzystencjalne doświadczenie starości w literaturze, red. E. Gleń, J. Jokiel, M. Szladowski, Opole 2008.

Дудараў А., Вечар, [w:] idem, Князь Bimay̆m. П’есы, Мінск 2006.

Тэатральная Беларусь. Эниыклапедьия, т. 1, red. А.С. Сабалеўскі, Мінск 2002.

\section{Imperfect senility. The experience of senility in dramas Endgame by Samuel Beckett and Evening by Aleksiej Dudarau}

\section{Summary}

The article is devoted to the image of senility in two dramas - Endgame by Samuel Beckett and the dramatic text entitled Evening by Aleksiej Dudarau. The authoress introduces the conception of a character realized in analyzed texts and also shows the great importance of stage directions in the reconstruction of the title issue. In both dramas death appears very frequently. Death and senility are depicted as mutually conditioning experiences. The self-awareness of one's own temporality increases with age and the sensation that the nature is limited and mortal starts to cause the most intense feelings and emotions, triggers questions, full of disbelief about the sense and end of everything.

Keywords: senility, death, drama, passing of time, time, hope 


\section{Несовершенная старость. Опыт старости в пьесах Конеи игры Сэмюэля Беккета и Вечер Алексея Дударева}

Резюме

Статья посвящена образу старости в двух драматических произведениях - Конеи игры Сэмюэля Беккета и Вечер Алексея Дударева. Автор работы рассматривает концепции характеров, представленных в анализируемых текстах, а также обращает внимание на огромную роль ремарок для понимания главной идеи произведений. В обеих пьесах постоянно присутствует тема смерти. Смерть и старость показаны как взаимообуславливающие явления. Осознание кратковременности собственной жизни, а с ним и понимание ограниченности сил природы, усиливается с возрастом; что в итоге рождает важнейшие вопросы, полные недоверия, о смысле и конце всего сущего.

Ключевые слова: старость, смерть, пьеса, бренность, время, надежда 